\title{
Quality of life in perimenopausal women working in the health and educational system
}

\author{
Josefa Márquez Membrive ${ }^{1}$ \\ José Granero-Molina² \\ Ma José Solvas Salmerón ${ }^{3}$ \\ Cayetano Fernández-Sola ${ }^{4}$ \\ Carmen Ma Rodríguez López ${ }^{5}$ \\ Tesifón Parrón Carreño ${ }^{6}$
}

The objective of this study was to determine the association between the professional activity and the perceived quality of life in climacteric women who work in Health and Education. A descriptive and cross-sectional study was developed in a sample of 203 climacteric women, together with a correlation analysis of labor factors' influence on health-related quality of life. Significant differences were found between working women's quality of life and some labor conditions. The perceived quality of life in perimenopausal women who work in Education is higher than that of those working in Health $(p=0.004)$. Nursing professionals can develop health programs that deal with the work conditions that negatively influence the perceived quality of life in climacteric women.

Descriptors: Quality of Life; Climacteric; Occupational Health; Job Satisfaction.

\footnotetext{
${ }^{1}$ RN, M.Sc. in Nursing, Full Professor, Departamento de Enfermería y Fisioterapia, Universidad de Almería, Spain. E-mail: jmarquez@ual.es.

2 RN, Ph.D. in Health Sciences, Professor, Departamento de Enfermería y Fisioterapia, Universidad de Almería, Spain. E-mail: jgranero@ual.es.

${ }^{3}$ RN, Complejo Hospitalario Torrecárdenas, Almería, Spain. E-mail: manuferrer78@hotmail.com.

${ }^{4}$ RN, Ph.D. in Nursing, Professor, Departamento de Enfermería y Fisioterapia, Universidad de Almería, Spain. E-mail: cfernan@ual.es.

${ }^{5}$ Physician, Ph.D. in Medicine, Full Professor, Departamento de Neurociencia y Ciencias de la Salud, Universidad de Almería, Spain. E-mail: cmrodrig@ual.es.

${ }^{6}$ Physician, Ph.D. in Medicine, Associate Professor, Departamento de Neurociencia y Ciencias de la Salud, Universidad de Almería, Spain. E-mail: tpc468@ual.es.
} 


\section{Qualidade de vida em mulheres climatéricas que trabalham no sistema sanitário e educativo}

O objetivo deste estudo foi determinar a associação entre a atividade profissional e a qualidade de vida percebida em mulheres climatéricas que trabalham nas áreas da saúde e educação. Realizou-se estudo descritivo e transversal, numa amostra de 203 mulheres climatéricas, juntamente com análise correlacional da influência dos fatores de trabalho na qualidade de vida, relacionada à saúde. Encontraram-se diferenças significativas entre a qualidade de vida das trabalhadoras e algumas variáveis laborais. A qualidade de vida percebida pelas mulheres perimenopáusicas que trabalham na área da educação é superior à daquelas que trabalham na área da saúde $(p=0,004)$. Os profissionais de enfermagem podem elaborar programas de saúde que abordem as condições de trabalho que influenciam negativamente a qualidade de vida percebida pelas mulheres climatéricas.

Descritores: Qualidade de Vida; Climatério; Saúde Ocupacional; Satisfação no Emprego.

\section{Calidad de vida en mujeres climatéricas que trabajan en el sistema sanitario y educativo}

El objetivo de este estudio fue determinar la asociación entre la actividad profesional y la calidad de vida percibida en mujeres climatéricas que trabajan en las áreas sanitaria y educativa. Se realizó un estudio descriptivo y transversal, en una muestra de 203 mujeres climatéricas, junto al análisis correlacional de la influencia de los factores laborales en la calidad de vida relacionada con la salud. Se encontraron diferencias significativas entre la calidad de vida de las trabajadoras y algunas condiciones laborales. La calidad de vida percibida por las mujeres perimenopáusicas que trabajan en educación es superior a la de las que trabajan en salud $(p=0,004)$. Los profesionales de Enfermería pueden elaborar programas de salud, que aborden las condiciones de trabajo que influyen negativamente en la calidad de vida percibida por las mujeres climatéricas.

Descriptores: Calidad de Vida; Climaterio; Salud Ocupacional; Satisfacción en el Trabajo.

\section{Introduction}

Quality of life has turned into a reference for the so-called "state of wellbeing" in developed countries. This broad concept receives the complex influence of multiple factors, including: psychological condition, independence level, social relations, environmental characteristics and physical health.

Satisfaction with health is one of the fundamental components of perceived quality of life, which is why a term was proposed to adapt its denomination to the contents of the quality of life concept: Health-Related Quality of Life (HRQoL).

This concept includes, among other factors, the work-related quality of life $\mathrm{e}^{(1)}$ and the possible influence the endocrine modifications of ovarian failure may exert on women's perceived quality of life ${ }^{(2-4)}$. Therefore, from the HRQoL perspective, the consequences of the climacterium should be considered as a specific aspect of health-related quality of life. The increased life expectancy of the general population and of women in particular (there will be more than ten million climacteric women in Spain during this century) has turned women's health care in this phase of life into a priority; the way this should be accomplished, however, represents one of the main sources of public health debate. Although agreement exists that the approach of the climacterium should be primarily educative and preventive ${ }^{(5-6)}$, being 
able to develop it unavoidably implies knowledge about symptom-related factors and the determination of its influence on quality of life. Various publications on both issues $^{(7-9)}$ evidence socio-demographic factors, including the number of children, social class, culture or work ${ }^{(10-13)}$ that have demonstrated their role as relevant variables in the clinical vivacity about the climacterium and menopause.

Most papers published specifically analyze labor activities, but a review about their influence on menopausal women's quality of life reveals contradictory results. While some studies found no relation between work, menopause and quality of life $\mathrm{e}^{(2,14-15)}$, others show that working women experience less specifically menopausal symptoms than housewives ${ }^{(16-17)}$. Some authors(18) appoint that the satisfaction level of menopausal women with work is positively related to a lesser display of somatic and psychological symptoms. This same relation is also present in another study that also considers ${ }^{(19)}$ the need to incorporate the range of work-related variables in research on quality of life in the climacterium.

The goal of this study is to describe and analyze the association between labor conditions and quality of life among climacteric women working in health and education.

\section{Method}

This descriptive and cross-sectional study incorporates a correlation analysis of the variables involved, searching for associations among them. Data were collected in 2007-2008, in a reference population of climacteric women, between 45 and 65 years old, who worked in the health and educative sectors in the province of Almería (Spain). This age range, previously used in construction and validation process of specific menopause scales among Spanish women ${ }^{(20)}$, collects information on the variable nature of the start, continuation and disappearance of climacteric symptoms, also coinciding with the final phase of the professional life of women which, in Spain, extends until the age of 65 years. Group-1. Nurses who work in hospitals (Complejo Hospitalario Torrecárdenas) and in Primary Health Care services (Zonas Básicas de Salud in the Almería-Centro Health District). Group-2. Teachers at Secondary Education Institutions and the Universidad de Almería. Both areas were chosen because most workers are women, their nature is clearly social and their labor conditions are clearly distinctive.
In a reference population of 429 women who attended to the inclusion criteria, the sample size was estimated using QUESTA software, with a 95\% confidence level. The inclusion criteria were: being a woman, age between 45 and 65 years, who were working in health or education in the province of Almería (Spain) at the time of data collection. The definitive sample comprised 203 active women: 86 nurses working in health and 117 teachers, selected from the original list through simple random sampling. After obtaining permission to develop the research, the primary investigator contacted the boards of the job centers, which provided the data needed to select and contact the participants from the Secondary Education Institutions, University Departments, Health Centers and the Hospital Complex. Three investigators made appointments by telephone with all participating workers, with a view to data collection at the different job centers. Data were collected during the rest hours of the Secondary Education and University teachers, as well as the Hospital and Health Center workers. In specific meeting rooms at the job centers, the investigator presented and explained the study aims to the women and, after showing a data confidentiality commitment, invited them to participate, handed over the survey and gave them time to answer it, demonstrating availability to clarify any kind of doubt. None of the women invited refused to participate. Data were collected during approximately ten months, between September 2007 and June 2008. The self-administered questionnaire contained 73 questions, distributed in three parts:

$1^{\text {st }}$ Part: collects data on socio-demographic characteristics and the climacteric profile, measured through closed questions and distinguishing among three subgroups: premenopause ( $>45$ years and normal menstruation), climacterium ( $>45$ years, irregular menstruation in number or quantity) and postmenopause (>45 years, as from 12 months without menstruation).

$2^{\text {nd }}$ Part: explores the labor conditions through 24 closed questions, distributed in two blocks. The first 18 items are part of the Quality of Life at Work Survey (QLWS) (21), which the Spanish Ministry of Labor and Social Affairs periodically applies. The instrument explores workers' quality of life through objective information about the actual situations in which activities are accomplished in the work environment, together with subjective information about the workers' personal perceptions about their labor conditions and relations. The six remaining items, addressing work conditions and the women's type of occupational exposure, were obtained from the Spanish V National Survey of Work Conditions(22). 
$3^{\text {rd }}$ Part: contains 31 items and collects information about quality of life and menopause through the use of the Cervantes Scale(20). This questionnaire, validated for menopause research in Spanish women, measures the global quality of life score, as well as scores in different areas or domains (psychic, partner relation, vasomotor symptoms, aging). Short, practical to apply and easy to correct, this scale uses a score range from 0 to 5 to measure the presence of symptoms, in which 0 represents the absence of the symptom and 5 the presence of a very severe symptom. Therefore, lower scores correspond to a better quality of life.

Calculations were elaborated in SPSS 17.0 software. First, data were subject to descriptive analysis: determination of means and standard deviations (quantitative variables) and percentages (categorical variables). Next, the relation between quality of life and work conditions was analyzed: Pearson's correlation test, Spearman's test and Kendal's Tau-b test were used; Student's t-test was used to compare means (MannWhitney for those variables in which $n<30$ ); the chisquare test was used to compare qualitative variables.

\section{Results}

The mean age of the women in the simple was 50.61 years and similar in both sectors. About $69 \%$ were married or had a fixed partner. The mean number of children was 1.92. In general, the collected data show homogeneous climacteric patterns in both groups (Table 1 ).

Table 1 - Climacteric condition of women in the simple according to professional activity (Health-Education)

\begin{tabular}{lccc}
\hline Variable & $\begin{array}{c}\text { Total } \\
\text { sample }(\mathbf{n})\end{array}$ & $\begin{array}{c}\text { Health } \\
\text { sector }(\mathbf{n})\end{array}$ & $\begin{array}{c}\text { Education } \\
\text { sector }(\mathbf{n})\end{array}$ \\
\hline Premenopausal & 80 & 34 & 46 \\
Perimenopausal & 39 & 13 & 26 \\
Postmenopausal & 84 & 39 & 45 \\
\hline
\end{tabular}

The global quality of life score was lower among women who worked in the Education System (36.56) tan in the Health System (42.34), which means a higher perceived quality of life, although differences were only significant in the group of perimenopausal women (Table 2).

Table 2 - HRQoL in climacteric women

\begin{tabular}{|c|c|c|c|c|c|c|c|}
\hline \multirow{2}{*}{ Variable } & \multicolumn{2}{|c|}{ Total sample } & \multicolumn{2}{|c|}{ Health sector } & \multicolumn{2}{|c|}{ Education sector } & \multirow{2}{*}{$\mathbf{P}^{\dagger}$} \\
\hline & Mean & $\mathrm{SE}^{*}$ & Mean & SE $^{*}$ & Mean & $\mathrm{SE}^{*}$ & \\
\hline Global quality of life & 39.01 & 20.58 & 42.34 & 22.53 & 36.56 & 18.75 & ns \\
\hline Premenopause & 37.25 & 22.71 & 38.02 & 25.84 & 36.67 & 18.97 & ns \\
\hline Perimenopause & 43.97 & 18.98 & 56.38 & 16.88 & 37.76 & 17.76 & $(p=0.003)$ \\
\hline Postmenopause & 38.39 & 19.76 & 41.43 & 19.52 & 35.75 & 19.80 & ns \\
\hline Menopause and health & 19.65 & 12.49 & 20.95 & 12.34 & 18.69 & 11.87 & ns \\
\hline Psychic domain & 8.56 & 7.36 & 9.79 & 8.69 & 7.65 & 6.69 & ns \\
\hline Sexuality & 7.27 & 4.29 & 7.74 & 4.71 & 6.92 & 3.94 & ns \\
\hline Partner relation & 3.44 & 3.54 & 3.86 & 4.23 & 3.13 & 2.91 & ns \\
\hline Vasomotor symptoms & 3.89 & 4.18 & 4.05 & 4.27 & 3.76 & 4.28 & ns \\
\hline Health & 8.53 & 5.61 & 9.11 & 5.67 & 8.10 & 5.55 & ns \\
\hline Aging & 7.21 & 5.26 & 7.77 & 5.58 & 6.79 & 5.9 & ns \\
\hline
\end{tabular}

*SE = standard error

${ }^{+}$Comparison between health and education sector $\mathrm{ns}=$ not significant

The scores obtained for climacteric women's workrelated quality of life (Table 3 ) highlighted that both stress levels and degrees of satisfaction with their work were very similar between health and education sectors ("liking the job" and "job stability" are the most expressed motives). Significant differences were found, though, with regard to satisfaction levels related to physical environment and work organization variables. In both cases, expressed satisfaction levels were higher among women in the education sector. In comparison with women working in health institutions, about $90 \%$ of women working in education never made physical efforts, with significant differences.

With regard to the work conditions in both sectors under analysis (Table 4), higher levels of exposure to biological (61.6\%) and chemical (54.7\%) contaminating agents, vibrations (31.4\%) and radiations (25.6\%) stand out among women working in the Health System. 
Table 3 - Perceived work-related quality of life among climacteric women

\begin{tabular}{|c|c|c|c|c|}
\hline Variable & Total sample (n) & Health sector $(n)$ & Education sector $(\mathrm{n})$ & $\mathbf{P}^{*}$ \\
\hline Attractive work & & & & ns \\
\hline Always or frequently & 82 & 33 & 49 & \\
\hline Sometimes & 107 & 50 & 57 & \\
\hline Never or hardly ever & 9 & 2 & 7 & \\
\hline Boring work & & & & ns \\
\hline Always or frequently & 9 & 4 & 5 & \\
\hline Sometimes & 87 & 46 & 41 & \\
\hline Never or hardly ever & 93 & 33 & 60 & \\
\hline Makes physical efforts & & & & $p<0.001$ \\
\hline Always & 7 & 5 & 2 & \\
\hline Frequently & 20 & 19 & 1 & \\
\hline Sometimes & 43 & 34 & 9 & \\
\hline Hardly ever & 47 & 18 & 29 & \\
\hline Never & 84 & 9 & 75 & \\
\hline Type of contract & & & & $p=0.006$ \\
\hline Undetermined & 189 & 84 & 105 & \\
\hline Temporary & 9 & 0 & 9 & \\
\hline Type of job & & & & ns \\
\hline Full-time & 193 & 82 & 111 & \\
\hline Part-time & 7 & 3 & 4 & \\
\hline Type of Shift & & & & $p<0.001$ \\
\hline Shift without lunch break & 172 & 85 & 87 & \\
\hline Split shift & 25 & 0 & 25 & \\
\hline Work hours & & & & $p<0.001$ \\
\hline Morning & 155 & 59 & 96 & \\
\hline Afternoon & 1 & 0 & 1 & \\
\hline Night & 5 & 4 & 1 & \\
\hline Morning and afternoon & 24 & 6 & 18 & \\
\hline Morning, afternoon and night & 17 & 17 & 0 & \\
\hline Works weekends & 45 & 30 & 15 & $p<0.001$ \\
\hline Flexibility to take a day off & 120 & 55 & 54 & $p<0.001$ \\
\hline Satisfied with salary & 77 & 21 & 56 & $p<0.001$ \\
\hline Years of work & 25.44 & 26.67 & 24.54 & $p=0.010$ \\
\hline Degree of satisfaction & 6.62 & 6.42 & 6.77 & ns \\
\hline Stress level & 6.40 & 6.56 & 6.29 & ns \\
\hline Satisfaction level with physical environment & 5.96 & 5.64 & 6.20 & $p=0.021$ \\
\hline Satisfaction level with work organization & 6.18 & 5.51 & 6.67 & $p<0.001$ \\
\hline
\end{tabular}

*Comparison between health and education sector $\mathrm{ns}=$ not significant

Table 4 - Work conditions according to job sector

\begin{tabular}{|c|c|c|c|c|}
\hline Variables & Total sample (n) & Health sector $(n)$ & Education sector (n) & $\mathbf{p}^{*}$-value \\
\hline Exposure to biological contaminants & 72 & 53 & 19 & $p<0.001$ \\
\hline Exposure to noise & & & & ns \\
\hline Very low & 57 & 20 & 37 & \\
\hline Not very high but annoying & 81 & 34 & 47 & \\
\hline High & 57 & 29 & 28 & \\
\hline Comfortable temperature & 49 & 25 & 24 & ns \\
\hline Exposure to vibrations & 34 & 27 & 7 & $p<0.001$ \\
\hline Exposure to radiations & 25 & 22 & 3 & $p<0.001$ \\
\hline Exposure to chemical contaminants & 54 & 47 & 7 & $p<0.001$ \\
\hline
\end{tabular}

*Comparison between health and education sector $\mathrm{ns}=$ not significant 
The results of the relation between work variables and the global HRQoL score in both sectors (Table 5) show that the nurses who were most satisfied with their work displayed a better quality of life $(p=0.003)$, similar to those who considered their work attractive $(p=0.003)$, against worse scores for those who considered it boring $(p=0.008)$. Both the stress level $(p=0.030)$ and exposure to noise $(p=0.012)$ determined a worse quality of life, as opposed to exposure to comfortable temperature at the workplace, which is related with an increase in these workers' perceived quality of life $(p=0.019)$.

As for educational workers, the teachers who were most satisfied with their work $(p=0.002)$ and its organization $(p=0.002)$ showed better quality of life scores; the same is true for professionals who considered their work attractive $(p=0.007)$, against worse scores for those who considered their work was boring $(p=0.001)$. The teachers who obtained better quality of life scores indicate lower stress levels and greater satisfaction with the physical environment of their workplace $(p<0.001)$ Likewise, significant differences in perceived quality of life were found between teachers who made physical efforts during their work shift and those who did not $(p=0.026)$, with lower scores for the former; this extends to exposure to physical contaminants at the workplace, which reduces these workers' perceived quality of life $(p=0.016)$. The degree of satisfaction with the salary was also identified as a determinant of perceived HRQOL $(p=0.024)$, without statistically significant differences when comparing the global score of women working in health and in education.

Table 5 - Relation between job variables and global HRQoL scores

\begin{tabular}{|c|c|c|c|c|c|c|}
\hline \multirow{3}{*}{$\begin{array}{l}\text { Job variables } \\
\text { Years of work }\end{array}$} & \multicolumn{6}{|c|}{ HRQoL } \\
\hline & \multicolumn{2}{|c|}{$\begin{array}{c}\text { Total sample } \\
39.01 \pm 20.58\end{array}$} & \multicolumn{2}{|c|}{$\begin{array}{c}\text { Health sector } \\
42.34 \pm 22.53\end{array}$} & \multicolumn{2}{|c|}{$\begin{array}{c}\text { Education sector } \\
36.56 \pm 18.75\end{array}$} \\
\hline & 25.44 & ns & 26.67 & ns & 24.54 & ns \\
\hline Degree of satisfaction & $6.62 \%$ & $p<0.001$ & $6.42 \%$ & $p=0.003$ & $6.77 \%$ & $p=0.002$ \\
\hline Attractive work & $40.4 \%$ & $p<0.001$ & $38.4 \%$ & $p=0.003$ & $41.9 \%$ & $p=0.007$ \\
\hline Boring work & $4.4 \%$ & $p<0.001$ & $4.7 \%$ & $p=0.008$ & $4.3 \%$ & $p=0.001$ \\
\hline Stress level & $6.40 \%$ & $p<0.001$ & $6.56 \%$ & $p=0.030$ & $6.29 \%$ & $\mathrm{p}<0.001$ \\
\hline Satisfaction physical environm & $5.96 \%$ & $p=0.001$ & $5.64 \%$ & ns & $6.20 \%$ & $p<0.001$ \\
\hline Physical effort & $13.3 \%$ & $p=0.001$ & $27.9 \%$ & ns & $2.6 \%$ & $p=0.026$ \\
\hline Undetermined contract & $93.1 \%$ & ns & $97.7 \%$ & ns & $89.7 \%$ & ns \\
\hline Full-time job & $95.1 \%$ & ns & $95.3 \%$ & ns & $94.9 \%$ & ns \\
\hline Shift without lunch break & $85.1 \%$ & ns & $98.8 \%$ & ns & $74.4 \%$ & ns \\
\hline Morning and afternoon hours & $88.7 \%$ & ns & $75.6 \%$ & ns & $98.4 \%$ & ns \\
\hline Works weekends & $22.2 \%$ & ns & $34.9 \%$ & ns & $12.8 \%$ & ns \\
\hline Flexibility to arrive late & $42.4 \%$ & ns & $45.3 \%$ & ns & $49.6 \%$ & ns \\
\hline Flexibility to take day off & $59.1 \%$ & ns & $76.6 \%$ & ns & $46.2 \%$ & ns \\
\hline Satisfaction salary & $37.9 \%$ & $p=0.018$ & $24.4 \%$ & ns & $47.9 \%$ & $p=0.024$ \\
\hline Satisfaction organization & $6.18 \%$ & $p=0.001$ & $5.51 \%$ & ns & $6.67 \%$ & $p=0.005$ \\
\hline Exposure biological contaminants & $35.5 \%$ & $p=0.034$ & $61.6 \%$ & ns & $16.2 \%$ & ns \\
\hline Exposure to noise & $68 \%$ & $p=0.002$ & $73.2 \%$ & $p=0.012$ & $64.1 \%$ & ns \\
\hline Exposure to chemical contaminants & $26.6 \%$ & $p=0.004$ & $54.7 \%$ & ns & $6 \%$ & $p=0.016$ \\
\hline Exposure to vibrations & $16.7 \%$ & ns & $31.4 \%$ & ns & $6 \%$ & ns \\
\hline Exposure to radiations & $12.3 \%$ & ns & $25.6 \%$ & ns & $2.6 \%$ & ns \\
\hline Comfortable temperature & $24.1 \%$ & $p=0.033$ & $29.1 \%$ & $p=0.019$ & $20.5 \%$ & ns \\
\hline
\end{tabular}

$\mathrm{ns}=$ not significant

HRQOL $=$ health-related quality of life

\section{Discussion}

Quality of life is a difficult concept, in view of its subjective, complex and multidimensional nature, involving several factors. The nurses' work conditions, whether they are teachers or caregivers, are perceived as determinants of $\mathrm{HRQOL}^{(1)}$, in addition to the possible influence deriving from physiological changes inherent in women, like in the case of the climacterium. The perceived global HRQoL in the study population is higher than the Spanish means found in other studies that used the same scale(20). This could be due to the fact that these studies were developed in the general population while, in the present study, all women are workers with 
a higher education degree, a factor that is widely related with quality of life in climacteric women. The results of our study signal that HRQOL is similar among nurses and teachers, except in the group of perimenopausal women, where workers in the education sector score higher; this derives from the latter's lower prevalence of exposure to certain work conditions that negatively interfere in the perceived quality of life. These data are in line with other studies(23), in which factors in the so-called "physical domain", including the conciliation between family-professional life, night or shift work receive the worst scores among health workers. These scores reflect clinical nurses' lesser satisfaction with the work organization, perceived salary, physical efforts and exposure to contaminants; all of these aspects, together with their hierarchical submission and emotional exhaustion deriving from patient care, are valued worse as determinants of HRQOL in more recent studies ${ }^{(24)}$. The fact that the quality of life in both groups was worse in the perimenopausal period coincides with other studies accomplished in the general population(25), given that this period covers women with irregular menstruation, in terms of quantity as well as number, and when the first symptoms of the climacterium start to appear.

One of the labor factors related with a better HRQoL in both groups was the consideration of work as attractive "always or frequently". Nevertheless, the figures found are lower than those published in the Survey of the Ministry of Labor and Social Affairs(21), which already concluded that a higher percentage of college graduates consider work more attractive than in the rest of the population. Similarly, the percentage of women that never or hardly ever considered work boring was higher than that published in the same survey(21). The degree of satisfaction with the work performed was clearly related with a better perceived HRQoL in both groups, a fact that has already been appointed in other publications $^{(18)}$.

The stress developed in the workplace is also related with a lower perceived HRQoL, among teachers as well as clinical nurses, although the differences between the date collected for both groups are smaller than those informed in other studies(21). The group of women who worked in health mentioned making more physical efforts at work. This result is probably related with the greater mental and psychological effort clinical nursing make; nevertheless, the association with the nurses' referred quality of life was not significant.

The present study data constitute an important source of research hypotheses to continue investigating the relation between work and quality of life in the climacterium. The results point towards the need to inform referral institutions, so that Occupational Nursing professionals at Occupational Risk Prevention Services can elaborate specific health programs for this population.

\section{Conclusions}

The HRQoL of the study population decreases in the perimenopausal period, but is nevertheless higher than that of the Spanish general population. Although the climacteric patterns found among women working in the health and education sectors are homogeneous, the HRQoL is higher among women working in education than in health, with differences that were only significant in the group of perimenopausal women. Working in health is associated with a lower perceived quality of life, and job satisfaction is associated with variables related to the physical environment and work organization. Work times, conciliation between family and professional life, physical efforts and exposure to contaminants receive the worst assessments.

\section{Limitations}

These study results need to be interpreted with caution because, although the sample follows strictly probabilistic criteria, the reference population was elected through convenience sampling, which needs to be taken into account before making any inference. The Cervantes Scale is a specific HRQoL measure for the menopause in Spanish women, whose original was developed in Spanish and is adapted to the research context. Any adaption needs to be validated for use in other contexts.

\section{References}

1. Rocha SSL, Felli VEA. Qualidade de vida no trabalho docente em enfermagem. Rev. Latino-Am. Enfermagem. 2004;12(1):28-35.

2. Blumel JE, Castelo-Branco C, Binfa L, Gramegna G, Tacla X, Aracena B, et al. Quality of life after the menopause: a population study. Maturitas. 2000;34(1):17-23.

3. Nisar N, Sohoo NA. Frequency of menopausal symptoms and their impact on the quality of life of women: a hospital based survey. Pak J Med Assoc. 2009;59(11):752-6.

4. Yangin Hb, Kukulu K, Sözer Ga. The perception of menopause among women Turkish. J Women J Aging. 2010;22(4):290-305. 
5. Olozábal JC, Pastor F, Montero J, García R. Adscripción a los diversos modelos de concebir la menopausia del personal sanitario de Salamanca. Cuad Med Psicosom Psiq Enlace. 2000;53:16-26.

6. Forouhari S, Khajehei M, Moattari M, Mohit M, Rad Ms, Ghaem $\mathrm{H}$. The effect of education and Awareness on the quality-of-life in postmenopausal women. Indian J Commun Med. 2010;35(1):109-14.

7. Jiménez de Luque $P$, Mejías Jiménez $A$, Avis Alvarado $M$, Biota Jiménez $P$, Sánchez Inchausti $F$. Altercaciones en la menopausia. ROL Enferm. 2006;29(4):64-6.

8. Lindh-Astrand $L$, Forman $M$, Hammar $M$, Kjelldren KI. Women's conception of the menopausal transition a qualitative study. J Clin Nurs. 2007;16(3):509-17.

9. Goncalves R, Merighi M. Reflexoes sobre a sexualidade durante a vivência do climatério. Rev. Latino-Am. Enfermagem. 2009;17(2):160-6.

10. Gambacciani M, Ciapone M, Cappagli B, Monteleone P, Benussi C, Bevilacqua G, et al. Effects of low-dose, continuous combined estradiol and norestisterone acetate on menopausal quality of life in early postmenopausal women. Maturitas. 2003;44(2):157-63.

11. Delgado A, Sánchez MC, Galindo I, Pérez C, Duque MJ. Actitudes de las mujeres ante la menopausia y variables predictoras. Atención Primaria. 2001;27(1):27-41.

12. Rossella E, Nappi, Esme A, Nijland. Women's perception of sexuality the menopause: Outcomes of a European telephone survey. Eur J Obstet Gynecol Reproduct Biol. 2008;137(1):10-6.

13. Kowalcek I, Rotte D, Banz C, Diedrich K. Women's attitude and perceptions towards menopause in different cultures: Cross-cultural and intra-cultural comparison of pre-menopausal and post-menopausal women in Germany and in Papua New. Maturitas. 2005;51(3):227-35.

14. Dueñas JL, Durán M, Abad P. Calidad de vida en las mujeres españolas sintomáticas. En Dueñas Díez JL. Climaterio y calidad de vida. Madrid: Masson; 2001. p. 97-102.

15. Salazar MA, Paravic KT. Desempeño laboral y climaterio en trabajadoras de instituciones públicas. Rev Med Chil. 2005;133(3):315-22.

16. Olaolorun FM, Lawoyin A. Experience of menopausal symptoms by women in an urban community in Ibadan, Nigeria. Menopause. 2009;16(4):822-30.

17. Lee MS, Kim JH, Park MS, Yang YH, Ko SD, Joe SH. Factors influencing the severity of menopause symptoms in Korean post-menopausal women. J Korean Med Sci. 2010;25(5):758-65.

18. Dennerstein L, Dudley L, Guthrie E, Barrett-Connor J. Life satisfaction, symptoms, and the menopausal transition. Medscape Women's Health. 2000;5(4):E4.
19. Im EO, Meleis AI. Women's work and symptoms during midlife: Korean immigrant women. Women's Health. 2001;33(1-2):83-103.

20. Palacios S, Ferrer Barriendos J, Parrilla JJ, CasteloBranco C, Manubens M, Alberich X, et al. Calidad de vida relacionada con la salud en la mujer española durante la perimenopausia y posmenopausia. Desarrollo y validación de la Escala Cervantes. Med Clin. 2004;122(6):205-11. 21. Ministerio de Trabajo y Asuntos Sociales (ES). Encuesta sobre calidad de vida en el trabajo. Madrid: Ministerio de Trabajo y Asuntos Sociales; 2004.

22. Instituto Nacional de Seguridad e Higiene en el trabajo. $V$ encuesta nacional de condiciones de trabajo. Madrid: Instituto Nacional de Seguridad e Higiene en el trabajo; 2004.

23. Andrades Barrientos $L$, Valenzuela Suazo $S$. Fatores associados a qualidade de vida de enfermeiras hospitalares chilenas. Rev. Latino-Am. Enfermagem. 2007;15(3):480-6.

24. Ríos Assalvi K, Barbosa DA, Gonçalves A, Belasco S. Avaliação de qualidade de vida e depressão de técnicos e auxiliares de enfermagem. Rev. Latino-Am. Enfermagem. 2010;18(3):413-20.

25. Mishra GD, Brown WJ, Dobson AJ. Physical and mental health: changes during menopause transition. Qual Life Res. 2003;12(4):405-12.
Received: Dec. $29^{\text {th }} 2010$ Accepted: Sept. 20 2011 